\title{
THERAPEUTIC EFFICACY OF A CYSTEINE PROTEASES INHIBITOR (PHENYL VINYL SULFONE) EITHER ALONE OR COMBINED WITH NIGELLA SATIVA ON EXPERIMENTAL CRYPTOSPORIDIOSIS
}

\author{
WAFAA M. ZAKI ${ }^{1,2^{\star}}$ and YASMIN O. EL-AMIR ${ }^{2,3}$
}

Department of Medical Parasitology ${ }^{1}$, Faculty of Medicine, Suez Canal University, Egypt, Department of Medical Laboratory Technology ${ }^{2}$, Faculty of Applied Medical

Science, Jazan University, KSA and Department of Pathology and Clinical

Pathology ${ }^{3}$, Faculty of Veterinary Medicine, Assiut University, Egypt

( ${ }^{\star}$ Correspondence: <wafaa_zaki@hotmail.com>)

\begin{abstract}
The present study evaluated the efficacy of a cysteine protease inhibitor (PVS) either alone or combined with Nigella sativa in treatment of cryptosporidiosis in immunosuppressed mice. Seventy two mice were divided equally into eight groups: a normal control group (G1). Other received dexamethasone to induce immunosuppression (G2) acted as a dexamethasone immunosuppressed control. Six immunosuppressed groups were inoculated with infective dose of Cryptosporidum oocycts: (G3) infected control, (G4 \& G5) treated with PVS alone in a dose of $50 \mathrm{mg} / \mathrm{kg} \& 100 \mathrm{mg} / \mathrm{kg}$ respectively, (G6 \& G7) treated with same dose of PVS and combined with NS 500mg/kg, and (G8) was treated with Paromomycin $250 \mathrm{mg} / \mathrm{kg}$. Oocysts shedding were monitored from $2^{\text {nd }}$ to $24^{\text {th }}$ day post-infection. After mice scarification, blood was assessed for hepatorenal drug toxicity. Sections of ileum were subjected to histopathological examination. Mice treated with PVS $100 \mathrm{mg} / \mathrm{kg}$ combined with NS showed marked improvement with highest significant efficacy $(\mathrm{P} \leq 0.01)$ diminished oocyst shedding in $\mathrm{G} 6$ \& $\mathrm{G} 7$ by $91 \%$ \& $94 \%$ respectively, versus its efficacy when given alone in G4 \& G5 by $83 \%$ \& 87\% respectively or when compared with paromomycin effect in G8 (81\%). PVS in different doses showed no toxic effect on hepatorenal parameters.
\end{abstract}

Key words: Cryptosporidiosis, Cysteine proteases inhibitor, Nigella sativa, experimental study.

\section{Introduction}

Cryptosporidiosis was first discovered in the gastric mucosa of mice (Ernest Edward Tyzzer, 1907) and in human (Nime et al, 1976). Cryptosporidum is an intracellular protozoan family Cryptosporidiidae, phylum Apicomplexa. Two species are blamed in human infections; $C$. hominis that confined to man with anthroponotic transmission and $C$. parvum infecting a wide variety of animals especially livestock with zoonotic transmission (Leitch and He, 2011). C. parvum was accounted as a pathogen for the developing world; although now it is ubiquitous and found to be responsible for several waterborne outbreaks worldwide which was a compelling reason to consider it as a bioterrorism agent (Rotz et al, 2002). CDC listed C. parvum as a category B pathogen in a bioterrorism agent (Moran, 2002) with estimated hazard ratio 2.3 in toddlers (Kotloff et al, 2013). In immunocompetent patients infection gave an acute, self-limiting diarrheal of 1-2 week duration, in immunecompromised persons illness was much more severe (Tallant et al, 2016) and became life threatening (Tandon and Gupta, 2014). C. oocyst characterized by its resistance to conventional water purification techniques and the low infectious dose, it was determined that the $50 \%$ infective dose (ID50) of $C$. parvum for cryptosporidiosis seronegative is only 132 oocysts (Dupont et $a l, 1995)$ and 10 to 83 oocysts for C. hominis (Chappell et al, 2006). A patient could excrete up to a billion oocysts (Jokipii et al, 1986).

Nitazoxanide (FDA approved drug) is the basic therapeutic treatment for immunocompetent infected persons; nevertheless its role in parasitological clearance is doubtful (Amadi et al, 2002). Also it is ineffective in HIV patients (Amadi et al, 2009; Zulu et al, 2005). Also, Paromomycin for immunocom- 
pomised cases was not warranted (Hewitt et $a l, 2000)$. C. oocyst targets intestinal epithelium and excyst within lumen released four infective sporozoites by oocyst wall suture that facilitated by protozoan derived molecules i.e. cysteine and serine proteases (Forney et al, 1996) an arginine aminopeptidase (Okhuysen et al, 1996; Padda et al, 2002) ribosomal proteins, heat shock protein (Snelling et al, 2007) and secretory phospholipase $\mathrm{A}_{2}$ (Pollok et al, 2003). Therapies against these molecules were under advan-ced studies (Dinler and Ulutas, 2017).

Highlight for protease inhibitors was attained in research as it plays a crucial role in parasitic cell biology mainly protozoan (McKerrow et al, 2006). Cysteine protease inhibitor (K11777) is in late pre-clinical testing for submission with the US Federal Drug Administration (FDA) as an anti-chagasic drug (Sajid et al, 2011; Engel et al, 2010).

Immune system improvement is greatly supportive and with same importance of antimicrobial drug in cryptosporidiosis treatment in AIDS patients (Gargala, 2008). One of the most immune system supportive substances is Nigella sativa (NS) that proved several medicinal properties as anti-oxidant (Burits and Bucar, 2000) anti-inflammatory (El Mezayen et al, 2006) immune stimulant (Abel-Salam, 2012) anti-tumor (Banerjee et $a l, 2010)$ analgesic effect (Bashir and Qureshi, 2010) and antiparasitic properties (Baghdadi and Al-Mathal, 2011). NS proved effective in protozoa as Blastocystis hominis (El Wakil, 2007), Toxoplasma gondii (Mahdy et al, 2016), Giardia spp. (Bishara and Masoud, 1992), Trichomonas vaginalis (Aminou et al, 2016), Plasmodium yoelli nigeriensis (Okeola et al, 2011).

The current study aimed to evaluate the efficacy of a cysteine protease inhibitor (PVS) either alone or combined with Nigella sativa (NS) in treatment of cryptosporidiosis in immunosuppressed mice versus to a traditional anticryptosporidial drug, paromomy$\operatorname{cin}^{\circledR}$.

\section{Material and Methods}

Stool samples collection and examination: Thirty nine stool samples were taken from immunosuppressed patients in dialysis unit and oncology unit Suez Canal University Hospital complaining of diarrhea, from May 2016 to March 2017, after accepting participation with written informed consent. Samples were examined by direct saline and iodine smear, sedimentation procedures, Sheather's sugar flotation technique and Modified Ziehl-Neelsen acid fast stain (Garcia, 2007). C. oocyst was detected in ten samples without any other parasitic co-infections. These samples were used for completion of the study

Cryptosporidum purification: Positive stool samples were passed through stainless steel mesh sieve then preserved in $2.5 \%$ potassium dichromate, mixed, and stored at $4^{\circ}$, C. Oocysts purification was done on discontinuous sucrose gradient as described by Arrowood and Sterling (1987). Briefly, Sheather's sucrose solution was prepared of two dilutions $1: 2 \& 1: 4$. Layering $1 \mathrm{ml}$ of the $1: 4$ solutions slowly over layer of $10 \mathrm{ml}$ of the $1: 2$ solution then thirty milliliters of the fecal oocyst suspension was layered onto the 1:4 gradient. The tube was centrifuged at 4,500 for $30 \mathrm{~min}$ at $4{ }^{\circ} \mathrm{C}$. The oocysts-enriched layer was the layer occupying the interface between the sucrose layers. This layer was diluted with $20 \mathrm{ml}$ saline and centrifuged at 4,500 for $10 \mathrm{~min}$. Oocysts were counted by a hemocytometer then the suspension containing the required concentration for the infection $\left(1 \times 10^{4}\right.$ oocysts $\left./ \mathrm{ml}\right)$ was prepared by dilution of the organism in the appropriate amount of distilled water (Gafaar, 2007).

Drugs: Preparation of Phenyl Vinyl Sulphone (PVS) concentrations: Cysteine protease inhibitor, phenyl vinyl sulfone powder (Sigma-Aldrich, Germany) was added to distilled water at concentration of $5 \mathrm{mg} / \mathrm{ml}$; it was heated until totally dissolved. The stock solution was kept at $4^{\circ} \mathrm{C}$ until it was diluted. Treatment began on $5^{\text {th }}$ dpi and continued for 12 days. The doses were $50 \mathrm{mg} / \mathrm{Kg}$ and 
$100 \mathrm{mg} / \mathrm{Kg}$ once daily by oral route (Farid et al, 2013).

Nigella sativa: Nigella sativa seed oil used was in the form of soft gelatinous capsules supplied by Pharco Pharmaceutical Co. (Alexandria). Each capsule contains $450 \mathrm{mg}$ of $N$. sativa seed oil. It was given to the proper mice group with dose of $500 \mathrm{mg} / \mathrm{kg} /$ day (Farah et al, 2004) by stomach tube after its extraction from the capsules from the $5^{\text {th }} \mathrm{dpi}$ and continues for 12 days.

Paromomycin (Sigma Aldrich): An aminoglycoside used as anti-cryptosporidiosis drug in immunosuppressed cases; it was dissolved in PBS at $125 \mathrm{mg} / \mathrm{Kg}$ twice a day (Ndao et al, 2013).

Dexamethasone sodium phosphate: (EIPI$\mathrm{CO}, 10^{\text {th }}$ of Ramadan City): A synthetic cortico-steroids used for immunosuppression that was given as oral dose of $0.25 \mu \mathrm{g} / \mathrm{g} /$ day for 10 successive days before the inoculation of $C$. oocysts, the same dose was maintained throughout the experiment (Rehg, 1994).

Animal model for experimental infections: Swiss albino mice were purchased from faculty of veterinary medicine Suez Canal University. They were aged 3-5 weeks with average weight between $25 \& 35 \mathrm{~g}$. Housed under specific-pathogen-free condition in well ventilated cages with perforated covers, Bedding was changed every day. The mice were allowed to acclimatize laboratory environment for one week before the start of the experiment.

The experimental work was conducted in accordance with the internationally accepted principles for laboratory animal use and care as found in the United States guidelines (United States National Institutes for Health publication no. 85-23, revised in 1985). Mice stool was examined by direct wet saline smear, iodine and Sheather's sugar flotation method (Garcia, 2007), to exclude the presence of parasites.
Seventy two mice were divided randomly into eight equal groups (of nine each) as following: G1: Negative control, G2: Immunosuppresed control and G3: Positive infected immunosuppressed control.

G4 to G8 (experimental mice) were infected immunosuppressed and received drugs as following: G4 \& G5: received PVS alone in a dose of $50 \mathrm{mg} / \mathrm{kg} \& 100 \mathrm{mg} / \mathrm{kg}$ respectively, G6 \& G7: received PVS in a dose of $50 \mathrm{mg} / \mathrm{kg} \quad \& \quad 100 \mathrm{mg} / \mathrm{kg}$ respectively that combined with NS $500 \mathrm{mg} / \mathrm{kg}$ and G8: received Paromomycin $250 \mathrm{mg} / \mathrm{kg}$.

Proper treatment regimens were given from $5^{\text {th }}$ dpi and continued for 12 days.

Mice scarification: At the $24^{\text {th }}$ dpi, mice were sacrificed under light diethyl ether anaesthesia. From each mouse, ileum was rapidly removed and fixed in $10 \%$ formol saline and stained with $\mathrm{H} \& \mathrm{E}$ for histopathological study (Bancroft et al, 1996). Blood was taken using insulin needle 29 gauge by heart puncher. Then it was left to clot at $4 \mathrm{C}^{0}$ after that centrifugation for $10 \mathrm{~min}$ at $3000 \mathrm{rpm}$. Delicate aspiration for separated serum from clotted blood was done for assessment of drug toxicity.

Parameters for drug efficacy evaluation: aMonitoring clinical signs and survival rate in each group. b-The oocytes' shedding was done daily from the $2^{\text {nd }}$ to the $24^{\text {th }}$ dpi for each mice group. Fresh fecal pellets were collected every day from each mouse in the studied groups over the experimental period, each sample was suspended in $10 \%$ formalin and homogenized, then, $1 \mathrm{mg}$ was prepared as a fecal smear and stained by modified Ziehl-Neelsen staining method. Oocytes' counts per 50 fields at magnification $\times 100$ were scored. Calculation of the inhibition rate $\%(x)$ was done to evaluate oocysts shedding reduction in $(\mathrm{G} 4, \mathrm{G} 5, \mathrm{G} 6, \mathrm{G} 7$ \& G8) compared to G3, it was done according to the following equation:

$$
\mathrm{X}=\frac{\text { Oocyst per gram of feces in }+ \text { ve control group }- \text { Oocyst per gram of feces in treated group }}{\text { Oocyst per gram of feces in }+ \text { ve control group }} 100
$$


The histopathological features of mice intestinal sections were examined. Assessment of drug toxicity: Measuring liver function; serum enzymes alanine transaminase (ALT) and aspartate transaminase (AST) and measuring kidney function; serum creatinine and serum urea levels. Measurements were done by using a clinical automatic analyzer (Hitachi, Japan) and commercial reagent kit (Roche Diagnostic, Mannheim, Germany) according to the manufacturer's protocol.

Statistical analysis: Oocysts shedding were performed on different days, means \pm S.D. Efficacy and inhibition rates (\%) were calculated. Significance of inhibition was tested using a paired Student's $t$-test. For drug toxicity assessment statistical analyses were performed using one-way ANOVA, and means were compared using Duncan's multiple range tests as a post hoc test at the 5\% probability level. $P$ value $<0.05$ was regarded significant.

\section{Results}

Clinical signs and survival rate: Monitoring daily activity and body weight of mice revealed average diminution for both of them in all infected groups (G3-G8), which regained only in treated groups with variable degrees, while infected untreated group appeared to be sick by wrinkled skin and hunched posture furthermore their feces became softer. Survival rate was $66.7 \%$ in G3 (three mice were died). While in G4 and G8 it was $77.8 \%$, two mice were died in each of them. Otherwise the remaining mice were kept alive till the study end.

Oocysts shedding and reduction $\%$ in experimental groups: Reduction in the median number of oocysts in treated versus infected control mice were calculated (Fig. 1 \& Fig. 2). It was revealed that infected non-treated control mice (G3) shed more oocysts than all other groups with gradual progressive increase from $8^{\text {th }}$ dpi with peak at $12^{\text {th }}$ day. It was gradually diminished till $14^{\text {th }}$ day when it showed another ascending increase at $16^{\text {th }}$ dpi then gradual decrease. PVS treated mice G4 \& G5 showed lower oocyst shedding than non-treated group G3 which was more significant in G5 especially from $16^{\text {th }}$ dpi till the study end (Fig. 1). Mice treated with PVS combined with NS showed much more significant decrease in oocysts shedding. In G7 there was great decreased to minimal amount at $12^{\text {th }}$ dpi till the study end (Fig. 2). Cryptosporidium oocysts isolated from human feces were given (Fig. 3).

Histopathological changes: Examination of ileum of G1 showed normal histological architecture (Fig. 4A). Examination of intestine from infected mice revealed presence of C. oocysts of different developmental stages near the intestinal epithelium brush border (Fig. 4B). There were necrosis of the intestinal epithelium, sloughing of the villi, edema and infiltration of inflammatory cells in the lamina propria (Fig. 4C). In some cases, there were thickening and flattening of the villi with hyperplasia of the intestinal epithelium (Fig. 4D). In PVS treated group, the villi were short and thick. There was infiltration of inflammatory cells in lamina propria and sub-epithelial edema (Fig. 5A). Mice treated with PVS combined with NS, the ileum showed few inflammatory cells and mild edema in lamina propria. Intestinal epithelium was slightly normal (Fig. 5B). Ileum of Paromomycin treated mice showed blunting of villi, sub-mucosal edema and hyperplasia of goblet cells (Fig. 5C).

Assessment of drug toxicity: 
Table 1: Clinical biochemistry parameters in different mice groups

\begin{tabular}{|l|l|l|l|l|}
\hline \multirow{2}{*}{ groups } & \multicolumn{2}{|c|}{ Liver function test } & \multicolumn{2}{c|}{ Kidney function test } \\
\cline { 2 - 5 } & \multicolumn{1}{|c|}{ ALT U/L } & \multicolumn{1}{c|}{ AST U/L } & Serum creatinine mg/dl & Serum urea mg/dl \\
\hline G1 & $48.7 \pm 7.56^{\mathrm{a}}$ & $67.1 \pm 5.83^{\mathrm{a}}$ & $0.53 \pm 0.04^{\mathrm{a}}$ & $50.86 \pm 8.83^{\mathrm{a}}$ \\
\hline G2 & $92.8 \pm 5.52^{\mathrm{b}}$ & $112.1 \pm 9.21^{\mathrm{b}}$ & $0.52 \pm 0.06^{\mathrm{a}}$ & $52.91 \pm 6.03^{\mathrm{a}}$ \\
\hline G3 & $116.4 \pm 5.76^{\mathrm{c}}$ & $139.3 \pm 6.74^{\mathrm{c}}$ & $0.55 \pm 0.03^{\mathrm{a}}$ & $56.11 \pm 5.34^{\mathrm{a}}$ \\
\hline G4 & $98.9 \pm 4.32^{\mathrm{b}}$ & $110.6 \pm 12.63^{\mathrm{b}}$ & $0.57 \pm 0.04^{\mathrm{a}}$ & $54.50 \pm 8.20^{\mathrm{a}}$ \\
\hline G5 & $88.7 \pm 6.50^{\mathrm{b}}$ & $106.4 \pm 8.46^{\mathrm{b}}$ & $0.50 \pm 0.07^{\mathrm{a}}$ & $53.12 \pm 7.51^{\mathrm{a}}$ \\
\hline G6 & $53.8 \pm 4.62^{\mathrm{a}}$ & $78.5 \pm 4.73^{\mathrm{a}}$ & $0.54 \pm 0.05^{\mathrm{a}}$ & $51.08 \pm 6.42^{\mathrm{a}}$ \\
\hline G7 & $50.1 \pm 7.86^{\mathrm{a}}$ & $75.7 \pm 5.38^{\mathrm{a}}$ & $0.52 \pm 0.04^{\mathrm{a}}$ & $51.28 \pm 3.53^{\mathrm{a}}$ \\
\hline G8 & $61.1 \pm 6.32^{\mathrm{a}}$ & $78.3 \pm 6.25^{\mathrm{a}}$ & $0.54 \pm 0.02^{\mathrm{a}}$ & $55.19 \pm 2.73^{\mathrm{a}}$ \\
\hline
\end{tabular}

One way ANOVA-test followed by Duncan's Multiple Range Test; $\mathrm{n}=9(P \leq 0.05)$ Means with different alphabetical superscripts in the same column are significantly different $($ at $\mathrm{P} \leq 0.05)$ and vice versa.

\section{Discussion}

The present work examine the efficacy of in vivo activity of a cysteine protease inhibitor (PVS) either alone or combined with NS for eradication of cryptosporidiosis in immunosuppressed mice. Dexamethasone was used for mice immunosuppression that caused increasing susceptibility to cryptosporidium infection, through immune system suppression, by decreasing of B cell count in the spleen and changing $\mathrm{CD} 4+/ \mathrm{CD} 8+$ ratio (Üner et al, 2003). Dexamethazone also lead to short incubation period and prolonged oocyte shedding this was in accordance with (Matsui, 2001) who found oocyst shedding in immunosuppressed mice to be about 24 days, and Lacroix, (2001) who noticed it to be 3-4 weeks. Monitoring clinical signs and survival rate in each group revealed that survival rate in immunosuppressed infected non treated group was $66.7 \%$ which agreed with Tarazona et al. (1998) who reported 66\% survival rate in post cryptosporidial infected animals. Clinical signs were ameliorated in all treated groups compared to non-treated groups, gradual weight and activity regaining was obtained only in treated groups. The present work showed that protease inhibitor (PVS) has a therapeutic effect in a dose dependent manner; it was more effective in $100 \mathrm{mg} \backslash \mathrm{Kg}$ than $50 \mathrm{mg} \mathrm{kg}$, either it was given alone or combined with NS.

A panel of VS related compounds was proven to give marked inhibition of cysteine peptidases from many protozoa (Ang et al, 2011; Sajid et al, 2011; Abdulla et al, 2008; Steverding et al, 2006) and helminthes (Helmy et al, 2008; Abdulla et al, 2007).
Okhuysen et al. (1996) reported that overwhelming infection in the cryptosporidiosis immunosuppressed patients is owed to autoinfection by thin walled oocyst rather than thick walled one, so challenging thin walled oocyst by excystation antagonist may have a successful effect.

Researches attributed success of protease inhibitor in treating parasite to two main factors, firstly: inhibition selectivity by differential uptake of parasite proteases rather than its human host homologues, Secondly: lesser amount of protease gene families in parasites, so host-origin lysosomal cysteine proteases are much higher than that for the parasite proteases, thus host protease activity is difficult to be eliminated in a short course treatment targeting an acute infection (McKerrow et al, 1999).

Both two lines of treatment (PVS alone or combined with NS) have succeeded to alter oocyte shedding pattern to be better than the untreated group and to be more effective than paromomycin. It was gradually decreesed after PVS alone treatment in G5 more than in G4 which was apparent on $16^{\text {th }} \mathrm{dpi}$ and the reduction on $12^{\text {th }}, 14^{\text {th }} 16^{\text {th }} \& 18^{\text {th }}$ dpi was significant $\mathrm{P} \leq 0.05$ efficacy of treatment were $87 \%$ and $83 \%$ in G5 \& G4 respectively (Fig. 1) On the other hand highly significant differences was attained in PVS treated groups combined with NS specially in $\mathrm{G} 7$ at $12^{\text {th }}$ dpi which was earlier than that reached by PVS alone, the efficacy rate reached to highest level $(94 \%)$ in G7 and $(91 \%)$ in G6 that was highly statistically significant $(\mathrm{P} \leq 0.01)$. Oocyst shedding gradually decreased to very low levels by 
$24^{\text {th }}$ dpi. So, PVS at a dose of $100 \mathrm{mg} \mid \mathrm{Kg}$ combined with NS is the superior choice in treating cryptosporidiosis immunosuppressed mice.

Regarding NS it helped in amelioration of infection and decreased oocyst shedding; this was in accordance with (Elrefaii, 2003). This was possibly through direct immune reconstitution effect, its antioxidants properties and its active biocide ingredients like alkaloid nigellicine and thymoquinone (Darakhshan et al, 2015). Active biocide ingredients could limit growth and development of protozoan parasite (Seddiek and Metwally, 2013).

High efficacy of the combination (PVS \& NS) in challenging cryptosporidiosis was explained by potential effect of PVS that directly interfere with oocyst excystation and host cell invasion; with the synergism of immune reconstitution of NS. Combined effect of drug therapy and immune system strengthen in treating cryptosporidiosis was proved, in a study that used nitazoxanide and highly active anti-retroviral therapy (HAART) in treatment of HIV cryptosporidiosis infected patients resulting in reduction of prevalence of infection; that was explained by combined direct effect of aspartyl protease inhibitor included in HAART and reconstitutional immune effect (Zardi et $a l, 2005)$. Immune status amelioration has a critical function in cryptosporidiosis clearance, especially in immune-compromised hosts; aggregated intraepithelial lymphocytes and $\mathrm{CD}^{+} \mathrm{T}$ cells gave higher reduction of $C$. oocyst load in infected mice (Tessema et al, 2009). Cryptosporidiosis clearance post anti-retroviral therapy was relapsed if CD4+ counts declined (Maggi et al, 2000).

Histopathological changes in G3 (control positive group) was explained with that parasites forms invaginate itself in microvillus border causing loss of the mature surface epithelium. This leads to marked shortening and fusion of the villi and lengthening of the crypts that is tried to be compensated by ac- celerated cell division. The parasite may enhance apoptosis in adjacent epithelial cells while inhibiting apoptosis in the infected cells to facilitate prolonged survival of the parasites (O’Hara and Chen, 2011).

Several vital physiological functions are carried out in the liver, amongst of them is detoxification. ALT and AST are biomarker enzymes that reflect functional integrity of liver. In the present study both liver enzymes were markedly elevated in G2 and G3 with significant result $(\mathrm{P}<0.05)$ compared to G1. These may attributed to corticosteroid therapy, while regressions of enzymes level occurred in the other infected treated groups with variable degrees. This result agreed with Hagopian et al. (2003) who found that enzymes including ALT were produced by intermediary metabolism occurring due to gluconeogenic and glycol-genic properties of dexamethasone. Hassona et al. (2017) reported a significant elevation in AST \& ALT activities after dexamethasone administration due to the liver damaged structural integrity. Regression of these enzymes in other infected treated groups may explained in PVS group on the basis of riding off the infection helped partially in regaining liver function while in G6 \& G7 with combined PVS \& NS therapy, the main cause of serum enzyme regression was that the effect of NS, which may be induced partly by improving the immunological host system and to some extent with its antioxidant effect (Mollazadeh and Hosseinzadeh, 2014). Aboelwafa and Yousef (2015) found that supplementation of hydrocortisone-treated rats with thymol reversed most of the biochemical, histological, and ultra-structural alterations of the liver. So, thymol has strong ameliorative effect against hydrocortisone-induced oxidative stress injury in hepatic tissues. Serum creatinine and urea may not affected by dexamethasone or cysteine protease therapy. In groups receiving combined PVS \& NS, protective effect of NS was expected. AbdelDaim and Ghazy (2015) found that NSO reduced serum hepatic and renal injury mark- 
ers. It reduced the lipid peroxidation in hepatic and renal tissues and elevated liver and renal antioxidant enzymes and glutathione levels.

\section{Conclusion}

The cysteine protease inhibitor PVS combined with Nigella sativa NS have a great efficacy in improving immune compromised cryptosporidiosis and alleviate the symptoms.

\section{References}

Abdel-Daim, MM, Ghazy, EW, 2015: Effects of Nigella sativa oil and ascorbic acid against oxytetracycline-induced hepato-renal toxicity in rabbits. Iran J. Basic Med. Sci. 18, 3:221-7.

Abdulla, MH, Lim, KC, Sajid, M, McKerrow, JH, Caffrey, CR, 2007: Schistosomiasis mansoni: novel chemotherapy using a cysteine protease inhibitor. PLoS Med. 4:e14. doi:10.1371/ journal. pmed. 0040014.

Abdulla, MH, O'Brien, T, Mackey, ZB, Sajid, M, Grab, DJ, et al, 2008: RNA Interference of Trypanosoma brucei Cathepsin B and L affects disease progression in a mouse model. PLoS Negl. Trop. Dis. 2:e298.

Abel-Salam, BK, 2012: immune stimulant Immunomodulatory effects of black seeds and garlic on alloxan-induced Diabetes in albino rat. Allergol. Immunopathol. (Madr.) 40, 6:336-40.

Aboelwafa, HR, Yousef, HN, 2015: The ameliorative effect of thymol against hydrocortisoneinduced hepatic oxidative stress injury in adult male rats. Biochem. Cell Biol. 93, 4:282-9.

Amadi, B, Mwiya, M, Musuku, J, Watuka, A, Sianongo, S, et al, 2002: Effect of nitazoxanide on morbidity and mortality in Zambian Children with cryptosporidiosis: a randomized controlled trial. Lancet 360:1375-80.

Amadi, B, Mwiya, M, Sianongo, S, Payne, L, Watuka, A, et al, 2009: High dose prolonged treatment with nitazoxanide is not effective for cryptosporidiosis in HIV positive Zambian children: a randomized controlled trial. BMC Infect. Dis. 9:195-8.

Aminou, HA, Alam-Eldin, YH, Hashem, HA, 2016: Effect of Nigella sativa alcoholic extract and oil, as well as Phaseolus vulgaris (kidney bean) lectin on the ultrastructure of Trichomonas vaginalis trophozoites. J. Parasit. Dis. 40, 3:70713.
Ang, KK, Ratnam, J, Gut, J, Legac, J, Hansell, E, et al, 2011: Mining a cathepsin inhibitor library for new antiparasitic drug leads. PLoS Negl. Trop. Dis. 5:e1023. doi:10.1371/journal. pntd .0001023 .

Arrowood, MJ, Sterling, CR, 1987: Isolation of Cryptosporidium oocysts and sporozoites using discontinuous sucrose and isopycnicpercoll gradient. J. Parasitol. 73, 2:314-9.

Baghdadi, HB, Al-Mathal, EM, 2011: Anticoccidial activity of Nigella sativa L. J. Food Agric. Environ. 9:10-17.

Bancroft, JD, Stevens, A, Turner, DR 1996: Theory and practice of Histological Techniques. $4^{\text {th }}$ ed. New York, London, San Francisco, Tokyo: Churchill Livingstone.

Banerjee, S, Azmi, A, Padhye, S, Singh, M, Baruah, J, et al, 2010: Structure-activity studies on therapeutic potential of thymoquinone analogs in pancreatic cancer. Pharm. Res. 27:114658.

Bashir, MU, Qureshi, HJ, 2010: Analgesic effect of Nigella sativa seeds extract on experimentally induced pain in albino mice. J. Coll. Physic. Surg. Pak. 20, 7:464-7.

Bishara, SA, Masoud, SI, 1992: Effect of $\mathrm{Ni}$ gella sativa extract on experimental giardiasis. New Egypt. J. Med. 7:1-3.

Burits, M, Bucar, F, 2000: Antioxidant activity of Nigella sativa essential oil. Phytother. Res.14, 5:323-8.

Chappell, CL, Okhuysen, PC, Langer-Curry, R, Widmer, G, Akiyoshi, DE, et al, 2006: Cryptosporidium hominis: Experimental challenge of healthy adults. Am. J. Trop. Med. Hyg. 75, 5: 851-7

Darakhshan, S, Pour, B, Hosseinzadeh, A, Colagar, A, Sisakhtnezhad, S, 2015: Thymoquinone and its therapeutic potentials. Pharmacol. Res. 95-96:138-58.

Dinler, C, Ulutas, B, 2017: Cryptosporidiosis in Ruminants: Update and current therapeutic appro-aches. Am. J. Anim. Vet. Sci. 12, 3:96-103.

DuPont, HL, Chappelln, CL, Sterling, CR, Okhuysen, PC, Rose, JB et al, 1995: The infectivity of Cryptosporidium parvum in healthy volunteers. N. Engl. J. Med. 332, 13:855-9.

El Mezayen, R, El Gazzar, M, Nicolls, MR, Marecki, JC, Dreskin, SC, et al, 2006: Effect of thymoquinone on cyclooxygenase expression and prostaglandin production in a mouse model of allergic airway inflammation. Immunol. Lett. 15: 106, 1:72-81. 
El Wakil, SS, 2007: Evaluation of the in vitro effect of Nigella sativa aqueous extract on Blastocystis hominis isolates. J. Egypt. Soc. Parasitol. 37, 3:801-13.

Elrefaii, MA, 2003: Trials on therapeutic effect of nigella sativa oil extract on Cryptosporidum parvum in experimentally infected mice. Egypt. J. Agricul Res, 81 .

Engel, JC, Ang, KK, Chen, S, Arkin, MR, McKerrow, JH, et al, 2010: Image-based highthrough put drug screening targeting the intracellular stage of Trypanosoma cruzi, the agent of Chagas' disease. Antimicrob Agents Chemother. 54: 3326-34.

Farah, KM, Aloji, Y, Shimizu, Y, Shiina, T, Nikami, H, 2004: Mechanisms of the hypoglycaemic and immuno-potentiating effects of Nigella sativa L. oil in streptozotocin induced diabetic hamsters. Res. Vet. Sci. 77, 2:123-9.

Farid, A, Ismail, A, Rabee, I, Zalat, R, El Amir, A, 2013: Study of the Efficacy of cysteine protease inhibitors alone or combined with praziquantel as chemotherapy for mice schistosomiasis mansoni, Int. J. Med. Sci. Eng. 7:850-6.

Forney, J R, Yang, S, Healey, MC, 1996: Protease activity associated with excystation of Cryptosporidium parvum oocysts. Parasitol. 82: 889-92.

Gaafar, MR, 2007: Effect of solar disinfection on viability of intestinal protozoa in drinking water. J. Egypt. Soc. Parasitol. 37, 1:65-86.

Garcia, LS, 2007: Macroscopic and Microscopic Examination of Fecal specimens, Diagnostic Medical Parasitology, $5^{\text {th }}$ ed. Washington, D.C. ASM Press.

Gargala, G, 2008: Drug treatment and novel drug target against Cryptosporidium. Parasite 15:275-81

Hagopian K, Ramsey JJ, Weindruch R, 2003: Caloric restriction increases gluconeogenic and transaminase enzyme activities in mouse liver. Exp. Gerontol. 38:267-78.

Hasona, NA, Alrashidi, AA, Aldugieman, TZ, Alshdokhi, AM, Ahmed, MQ, 2017: Vitis vinifera extract ameliorate hepatic and renal dysfunction induced by dexamethasone in albino rats. Toxics 5:11-9.

Helmy, MM, Fahmy, ZH, Sabryn HY, 2008: Fasciola gigantica: Evaluation of the effect of phenyl vinyl sulfone in vitro. Exp. Parasitol. 119, 1:125-34.

Hewitt, RG, Yiannoutsos, CT, Higgs, ES, Carey, JT, Geiseler, PJ, et al, 2000: Paromomy- cin: no more effective than placebo for treatment of cryptosporidiosis in patients with advanced human immunodeficiency virus infection: AIDS Clinical Trial Group. Clin. Infect. Dis. 31:108492.

Jokipii, L, Jokipii, AM, 1986: Timing of symptoms and oocyst excretion in human cryptosporidiosis. New Engl. J. Med. 315:1643-7.

Kotloff, KL, Nataro, JP, Blackwelder, WC, Nasrin, D, Farag, TH, et al, 2013: Burden and aetiology of diarrheal disease in infants and young children in developing countries (the Global Enteric Multicenter Study, GEMS): A prospective, case-control study. Lancet 382:209-22.

Lacroix, S, Mancassola, R, Naciri, M, Laurent, F, 2001: Cryptosporidium parvum-specific mucosal immune response in C57BL/6 neonatal and gamma interferon-deficient mice: role of tumor necrosis factor alpha in protection. Infect. Immun. 69:1635-42.

Leitch, GJ, He, Q, 2011: Cryptosporidiosis-an overview. J. Biomed. Res. 25, 1:1-16.

Maggi, P, Larocca, AM, Quarto, M, Serio, G, Brandonisio, O, et al, 2000: Effect of antiretroviral therapy on cryptosporidiosis and microsporidiosis in patients infected with human immunodeficiency virus type 1 . Eur. J. Clin. Microbiol. Infect. Dis. 19:213-7.

Mahdy, RF, El-Hadidy, W, Elachy, S, 2016: Effect of Nigella sativa oil on experimental toxoplasmosis. Parasitol. Res. 115:379-90.

Matsui, T, Fujino, T, Kajima J, Tsuji, M, 2001: Infectivity and oocyst excretion patterns of Cryptosporidium muris in slightly infected mice. J. Vet. Med. Sci. 63:319-20.

McKerrow, JH, Caffrey, C, Kelly, B, Loke, P, Sajid, M, 2006: Proteases in parasitic diseases. Ann. Rev. Pathol. 1:497-536.

McKerrow, JH, Engel, JC, Caffrey, CR, 1999: Cysteine protease inhibitors as chemotherapy for parasitic infections. Bioorg. Med. Chem. 4:639-44

Mollazadeh, H, and Hosseinzadeh, H. 2014: The protective effect of Nigella sativa against liver injury: A review. Iran. J. Bas. Med. Sci. 17, 12:958-66.

Moran, GJ, 2002: Threats in bioterrorism. II. CDC category $\mathrm{B}$ and $\mathrm{C}$ agents. Emerg. Med. Clin. North Am. 20:311-30.

Ndao, M, Nath-Chowdhury, M, Sajid M, Marcus, V, Mashiyama, ST, 2013: A cysteine protease inhibitor rescues mice from a lethal Cryptosporidium parvum infection. Antimicrob. 
Agents Chemother. 57, 12:6063-73.

Nime, FA, Burek, JD, Page, DL, Holscher, M A, Yardley, JH, 1976: Acute enterocolitis in a human being infected with the protozoan Cryptosporidium Gastroenterol. 70, 4:592-8.

O'Hara, SP, Chen, XM, 2011: The cell biology of Cryptosporidium infection. Microb. Infect. Inst. Pasteur 13, 8/9:721-30.

Okeola, VO, Adaramoye, OA, Nneji, CM, Falade, CO, Farombi, EO, et al, 2011: Antimalarial and antioxidant activities of methanolic extract of Nigella sativa seeds (black cumin) in mice infected with Plasmodium yoelli nigeriensis. Parasitol. Res. 108, 6:1507-12.

Okhuysen PC, Chappell, CL, Kettner, C, Sterling, CR, 1996: Cryptosporidium parvum metallo-aminopeptidase inhibitors prevent in vitro excystation. Antimicrob. Agents Chemother. 40, 12:2781-4.

Padda, R S, Tsai, A, Chappell, CL, Okhuysen, PC, 2002: Molecular cloning and analysis of the Cryptosporidium parvum aminopeptidase $\mathrm{N}$ gene. Int. J. Parasitol. 32:187-97.

Pollok, RC, McDonald, V, Kelly, P, Farthing, MJ, 2003: The role of Cryptosporidium parvum-derived phospholipase in intestinal epithelial cell invasion. Parasitol. Res. 90:181-6.

Rehg, JE, 1994: A comparison of anticryptosporidial activity of paromomycin with that of other aminoglycosides and azithromycin in immunosuppressed rats. J. Infect. Dis. 170:934-8.

Rotz, LD, Khan, AS, Lillibridge, SR, Ostroff, SM, Hughes, JM, 2002: Public health assessment of potential biological terrorism agents. Emerg. Infect. Dis. 8:225-30.

Sajid, M, Robertson, SA, Brinen, LS, McKerrow, JH, 2011: Cruzain: The path from target validation to the clinic. Adv. Exp. Med. Biol. 712:100-15.

Seddiek, SA, Metwallyn, AM, 2013: Anticoccidial activity of black cumin (Nigella Sativa) in rabbits. Assiut Vet. Med. J. 59, 138:85-96.
Snelling, WJ, Lin, Q, Moore, JE, Millar, BC, Tosini, F, et al, 2007: Proteomics analysis and protein expression during sporozoite excystation of Cryptosporidium parvum (Coccidia, Apicomplexa). Mol. Cell Proteo. 6, 2:346-55

Steverding, D, Caffrey, CR, Sajid, M, 2006: Cysteine proteinase inhibitors as therapy for parasitic diseases: advances in inhibitor design. Mini Rev. Med. Chem. 6, 9:1025-32.

Tallant, C, Huddleston, P, Alshanberi, A, Misra, S, 2016: Acute, severe cryptosporidiosis in an immunocompetent pediatric patient. Clin. Pract. 6, 2:83-7.

Tandon, N, Gupta, S, 2014: Cryptosporidiosis causing severe persistent diarrhea in a patient with multiple myeloma: A case report and brief review of literature. Ind. J. Med. Paedi. Onc. 35, 1:93-5.

Tarazona, R, Blewett, DA, Carmona, MD, 1998: $C$. parvum infection in experimentally infected mice: infection dynamics and effect of immunosuppression. Folia Parasitol. (Praha) 45: 101-7.

Tessema, TS, Dauber, E, Petry, F, 2009: Adoptive transfer of protective immunity from Cryptosporidium parvum-infected interferon-gamma $\&$ interleukin-12-deficient mice to naïve recipients. Vaccine 27:6575-81.

Tyzzer, EE, 1907: A sporozoan found in the peptic glands of the common mouse. Proc. Soc. Exp. Biol. Med;. 5:12-3.

Üner, A, Inceboz, T, Uysalci, M, Dagci, H, 2003: Immune deficiency and cryptosporidiosis in rats. Turk. J. Vet. Anim. Sci. 27:1187-91.

Zardi, EM, Picardi, A, Afeltra, A, 2005: Treatment of cryptosporidiosis in immunocompromised hosts. Chemother. 51:193-6.

Zulu, I, Kelly, P, Njobvu, L, Sianongo, S, Kaonga, K, et al, 2005: Nitazoxanide for persistent diarrhoea in Zambian acquired immune deficiency syndrome patients: A randomized controlled trial. Aliment. Pharmacol. Ther. 21:757-63.

\section{Explanation of figures}

Fig. 1: Efficacy of PVS (G4\& G5) and Paromomycin (G8) therapy on oocysts shedding in immunosuppressed infected mice compared to infected non treated mice $(\mathrm{G} 3)$. $* \mathrm{P}<0.05$.

Fig. 2: Efficacy of PVS combined with NS (G6\& G7) and Paromomycin (G8) therapy on oocysts shedding in immunosuppressed infected micecompared to infected non treated mice (G3). $* \mathrm{P}<0.05, * * \mathrm{P}<0.01$.

Fig. 3: Cryptosporidum oocysts in human isolates stained with modified Ziehl-Neelsen acid fast stain (X1000).

Fig. 4: Ileum from control group and cryptosporidium infected group. (A) normal architecture in normal control. (B-D) Cryptosporidium infected. (B) Cyptosporidium oocyst of different developmental stages in intestinal lumen (arrow). (C) Necrosis of intestinal epithelium, sloughing of intestinal villi, inflammatory cellular infiltration (arrow). (D) Hyperplasia of intestinal epithelium (arrow) H\&E.

Fig. 5: Photomicrograph of ileum from different groups (A) PVS treated. Shortage and thickening of villi: Infiltration of inflammatory cells in lamina propria and sub-epithelial edema (arrow). (B) PVS+NS treated group: Few inflammatory cells and mild edema in lamina propria. Intestinal epithelium is slightly normal. (C) Paromomycin treated group. Submucosal edema (star) \& hyperplasia of goblet cellsH\&E. 

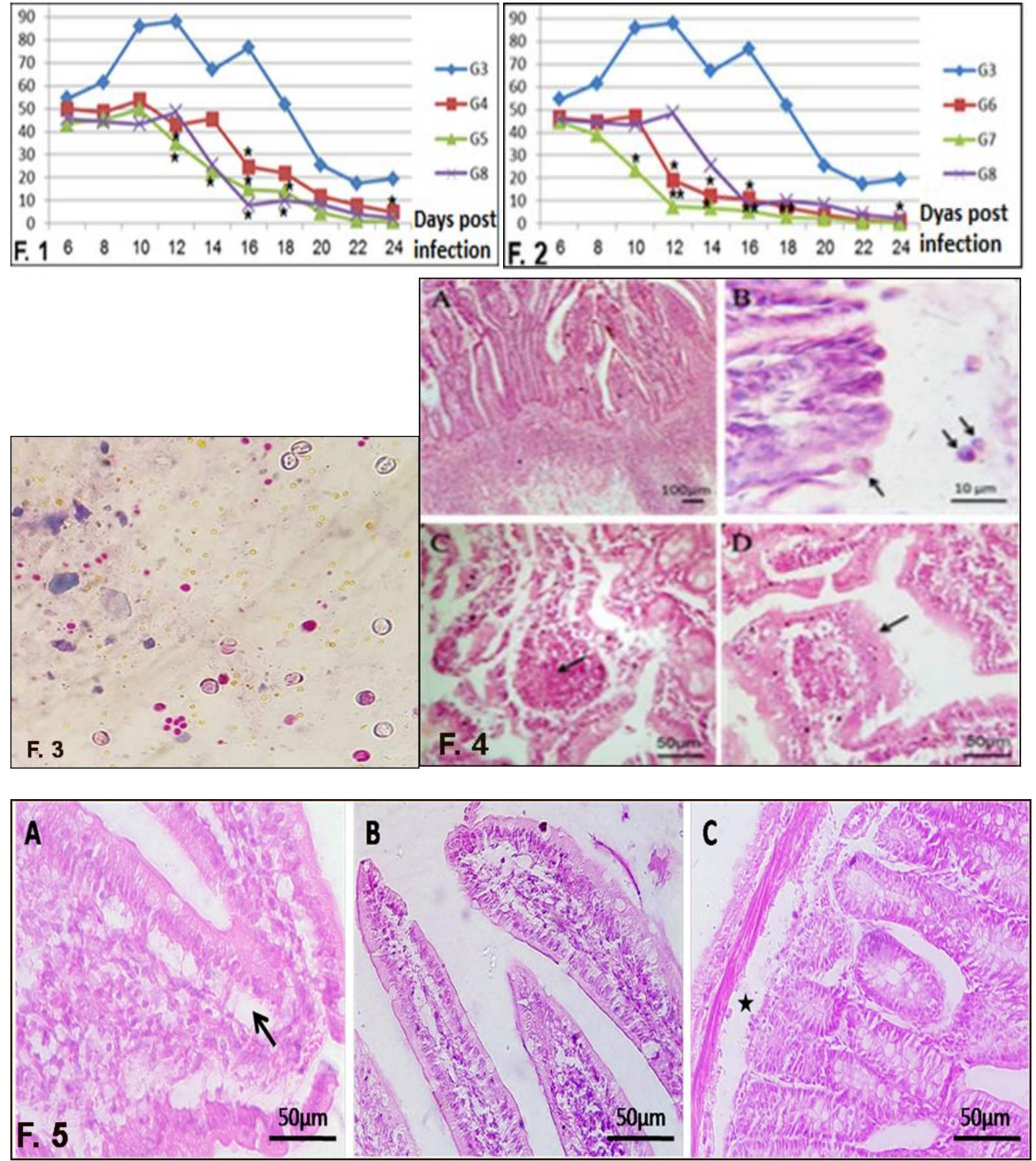